\title{
Implementasi Metode Naïve Bayes Dalam Penentuan Tingkat Kesejahteraan Keluarga
}

\author{
Made Ayu Dusea Widyadara*1, Roni Heri Irawan² \\ ${ }_{1,2}^{12}$ Universitas Nusantara PGRI Kediri \\ e-mail: *1madedara@gmail.com,${ }^{2}$ spidole.tech@gmail.com
}

\begin{abstract}
Abstrak-Tingkat kesejahteraan penduduk dalam suatu pemerintah daerah maupun pusat dapat ditunjukan dengan tingkat keberhasilnya mencapai tujuanya. Dalam rangka meningkatkan kesejahteraan penduduk, pemerintahan melaksanakan berbagai program untuk meningkatkan kesejahteraan penduduk. Namun dalam meningkatkan kesejahteraan penduduk tersebut dirasa kurang berjalan efektif, dimana seringkali ditemukan terjadinya kesalahan dalam menentukan kelayakan penerima bantuan atau kurang tepatnya dalam menentukan target sasaran penerima bantuan tersebut. Maka, diperlukan suatu sistem yang dapat digunakan untuk mengolah data kesejahteraan penduduk sehingga didapatkan informasi mengenai tingkat kesejahteraan keluarga dengan teknik data mining classification yang menggunakan metode Naive Bayes. Dengan adanya hasil prediksi kondisi penduduk setiap keluarga tersebut, diharapkan dapat memberikan informasi mengenai tingkat kesejahteraan keluarga dan dapat digunakan untuk membuat keputusan yang bertujuan untuk kesejahteraan penduduk. Data yang digunakan berdasarkan data Pemutakhiran Basis Data Terpadu (PBDT) penduduk rumah tangga yang di peroleh dari Badan Pusat Statistik (BPS) Kota Kediri melalui Badan Perencanaan, Pengembangan, Penelitian \& pengembangan (BARENLITBANG) pada Bidang Penelitian dan Pengembangan Kota Kediri. Data yang berasal dari PBDT digunakan sebagai variable input dan diolah dengan metode Naive Bayes. Dimana variable class nya dibagi menjadi empat yaitu, tingkat kesejahteraan dibawah $10 \%$, tingkat kesejahteraan dengan rentang $11 \%$ sampai dengan $20 \%$, tingkat kesejahteraan dengan rentang $21 \%$ sampai dengan $30 \%$ dan tingkat kesejahteraan dengan rentang $31 \%$ sampai dengan $\mathbf{4 0 \%}$. Hasil dari penelitian ini adalah aplikasi data mining dengan metode Naive Bayes dalam menentukan dan memprediksi tingkat kesejahteraan keluarga dengan tingkat akurasi mencapai $87 \%$.
\end{abstract}

\section{Kata kunci-komponen; Efektif, Kesejahteraan Keluarga, Nä̈ve Bayes, Tingkat Kesejahteraan}

\section{PENDAhUluan}

Keluarga Sejahtera sendiri merupakan Keluarga yang dibentuk berdasarkan perkawinan yang sah, mampu memenuhi kebutuhan hidup spiritual dan materi yang layak, bertaqwa kepada Tuhan Yang Maha Esa, memiliki hubungan yang selaras, serasi, dan seimbang antar anggota dan antar keluarga dengan masyarakat dan lingkungan [1].

Tingkat kesejahteraan penduduk dalam suatu pemerintahan dapat ditunjukan dengan tingkat keberhasilnya mencapai tujuanya dalam meningkatkan kesejahteraan penduduk, pemerintahan melaksanakan berbagai program untuk meningkatkan kesejahteraan penduduk. Namun dalam meningkatkan kesejahteraan penduduk dirasa kurang berjalan efektif, karena seringkali ditemukan kesalahan dalam menentukan kelayakan penerima bantuan atau kurang tepatnya sasaran dalam menentukan penerima bantuan tersebut[2].

Maka, diperlukan suatu sistem yang dapat digunakan untuk mengolah data untuk mendapatkan informasi mengenai tingkat kesejahteraan keluarga dengan teknik data mining classification yang menggunakan metode Naive Bayes. Pengolahan data dengan metode ini dilakukan karena selama ini masih belum diterapkannya metode dalam pengolahan data kependudukan yang mengakibatkan informasi tentang tingkat kesejahteraan penduduk belum dapat sesuai[3].
Dalam mewujudkan system tersebut dibuatlah system dengan menggunakan bahasa pemrograman web PHP dan menggunakan MySQL untuk pengolahan database dengan teknik data mining classification Naïve Bayes[4]. Dimana classification merupakan suatu proses untuk menentukan model atau fungsi yang menggambarkan dan membedakan kelas data atau konsep dengan tujuan memprediksi kelas untuk data yang tidak diketahui kelasnya. Model yang diturunkan didasarkan pada analisis dari training data. Model yang diturunkan dapat dipresentasikan dalam berbagai bentuk seperti If-Then klasifikasi, decision tree, dan sebagainya. [5].

Teknik classification merupakan pengelompokan data berdasarkan data training dan nilai atribut klasifikasi. Aturan pengelompokan tersebut digunakan untuk klasifikasi data baru ke dalam kelompok yang ada. Proses classification dibagi menjadi dua fase yaitu learning dan test. Pada fase learning, sebagian data yang telah diketahui kelas datanya digunakan untuk membentuk model perkiraan. Kemudian pada fase test model yang sudah terbentuk diuji dengan sebagian data lainnya untuk mengetahui akurasi dari model tersebut. Bila akurasinya telah memenuhi syarat model ini dapat digunakan untuk memprediksi kelas data yang belum diketahui.

Penelitian ini tak luput dari referensi penelitian sebelumnya yang merupakan bahan perbandingan serta 
tambahan untuk melakukan penelitian. Adapun penelitian sebelumnya yang menjadi bahan referensi adalah penelitian yang dilakukan oleh Maymunatu Labiybah Azzainabiy pada tahun 2015 dengan judul "Implentasi metode simple addative weighting (SAW) untuk Sistem Pendukung Keputusan Penentuan Warga Miskin Pada Kota Pekalongan" adalah penelitian yang menerapkan metode simple addative weighting (SAW) proses pendataan warga miskin dan meminimalisir terjadinya kesalahan kesalahan dalam pendaatan warga miskin dan data yang didapatkan digunakan sebagai data pendukung program warga miskin [6]. Sedangkan penelitian yang dilakukan Dini Puspita, Suparti, Yuciana Wilandari pada tahun 2013 dengan judul "Klasifikasi tingkat keluarga sejahtera dengan menggunakan metode regresi logistic ordinal dan fuzzy k-nearest neighbor" adalah penelitian dengan metode regresi logistic ordinal dan fuzzy k-nearest neighbor dalam mengkategorikan keluarga sejahtera dengan tingkat kesejaheraan berdasarkan BKKBN dengan Indikator keluarga sejahtera I (KS I) atau indikator kebutuhan dasar, indikator keluarga sejahtera II (KS II) atau indikator kebutuhan psikolog, indikator keluarga sejahtera III (KS III) atau indikator kebutuhan pengembangan, indikator keluarga sejahtera III Plus (KS III Plus) atau indikator aktualis[7][8].

\section{LANDASAN TEORI}

Teknik classification melakukan pengelompokan data berdasarkan data training dan nilai atribut klasifikasi. Aturan pengelompokan akan digunakan pada klasifikasi data baru ke dalam kelompok yang sudah ada. Menurut Han dan kamber (2006) bahwa classification adalah suatu proses untuk menemukan model atau fungsi yang menggambarkan dan membedakan kelas data atau konsep dengan tujuan memprediksikan kelas untuk data yang tidak diketahui kelasnya. Model yang diturunkan didasarkan pada analisis dari training data (yaitu objek data yang memiliki label kelas yang diketahui). Model yang diturunkan dapat direpresentasikan dalam berbagai bentuk seperti If-then klasifikasi, decision tree, dan sebagainya [5][9]. Sedangkan Naïve Bayes menurut Kenifesia (2007) merupakan sebuah metode dalam bidang probabilitas dan statistik, yang dinamai sesuai dengan penemunya, yaitu Thomas Bayes yang pertama kali mengemukakan teorema ini [10]. Misalkan E adalah kumpulan atribut. Dalam sudut pandang Bayesian, E diartikan sebagai "Bukti". Seperti biasa E di deskripsikan oleh pengukuran yang dibuat dari sebuah kumpulan atribut berjumlah $\mathrm{n}$.

Kenifesia (2007) menyatakan teorema ini berawal dari rumus peluang keajdian $\mathrm{A}$ sebagai $\mathrm{B}$ ditentukan dari peluang $B$ saat $A$, peluang A dan peluang B. Dimana $\mathrm{P}(\mathrm{A} \mid \mathrm{B})$ artinya peluang $\mathrm{A}$ jika diketahui kejadian $\mathrm{B}$
[10].

$$
\begin{gathered}
P(A \mid B)=\frac{P(B \cap A)}{\ldots \ldots .(1)} \\
P(A \mid B)=\frac{P(B \mid A) P(A)}{P(B)} \ldots \ldots .(2)
\end{gathered}
$$

Berdasarkan persamaan rumus tersebut, maka didapatkan persamaan rumus berikut ini

$$
P(A \cap B)=P(B \mid A) P(A) \ldots \ldots .(3)
$$

Persamaan diatas, dapat dituliskan seperti berikut ini,

$$
V_{M a p}=\underset{V j \in V}{\arg \max } \frac{P(a 1, a 2, a 3 \ldots \ldots \ldots a n \mid V j) P(V j)}{P(a 1, a 2, a 3 \ldots \ldots \ldots a n)} .
$$

Karena nilai $\mathrm{P}(\mathrm{a} 1, \mathrm{a} 2, \mathrm{a} 3, \ldots$ an) merupakan nilai yang konstan untuk semua vj, maka persamaan tersebut dapat dituliskan sebagai berikut,

$$
V_{\text {Map }}=\underset{V j \in V}{\arg \max } P(a 1, a 2, a 3 \ldots \ldots \ldots a n \mid V j) P(V j) \ldots
$$

Untuk menghitung $\mathrm{P}(\mathrm{a} 1, \mathrm{a} 2, \mathrm{a} 3, \ldots$, an $\mid \mathrm{vj})$ dapat semakin sulit karena jumlah term $\mathrm{P}(\mathrm{a} 1, \mathrm{a} 2, \mathrm{a} 3, \ldots$, an vj) yang sangat besar. Hal ini terjadi karena jumlah term tersebut sama dengan jumlah semua kombinasi posisi kata dikali dengan jumlah kategori yang ada.

Naïve Bayes menyederhanakan hal ini dengan asumsi fitur-fitur yang ada didalamnya tidak saling tergantung atau independen, setiap kata merupakan independen satu sama lain.

Dalam Naïve Bayes dinyatakan HMAP (Hypothesis Maximum Appropri Probability) dimana HMAP memaksimalkan nilai probabilitas masing-masing klas. HMAP inilah yang digunakan di dalam machine learning sebagai metode untuk mendapatkan hipotesis untuk suatu keputusan [7].

\section{Metode}

Sebagai proses awal pada penelitian ini maka disusunlah flowchart atau alur yang terdapat pada system klasifikasi tingkat kesejahteraan keluarga. 


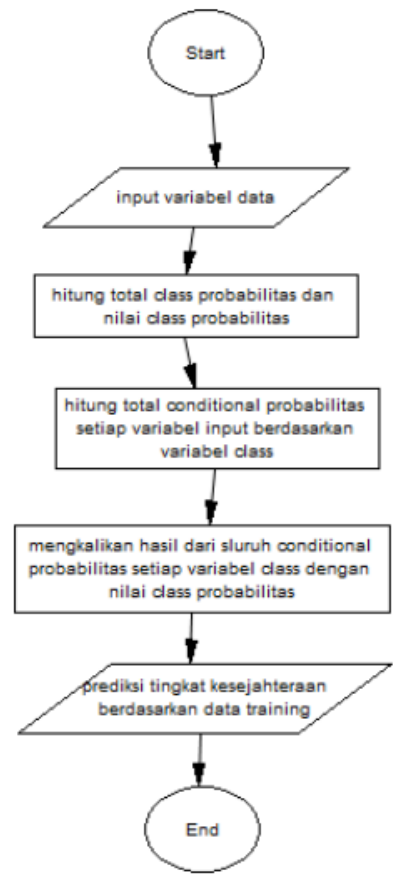

Gambar 1. Flowchart Proses Perhitungan Naïve Bayes Langkah-langkah untuk mengklasifikasikan tingkat kesejahteraan keluarga dengan metode Naive Bayes sesuai dengan flowchart pada gambar 1 , alur pertama memasukkan variabel data input sesuai dengan ketentuan. Kemudian, sistem menghitung class probabilitas yang telah ditentukan kemudian mencari conditional probabilitas berdasarkan pada variabel dengan class yang sesuai. Kemudian sistem melakukan perkalian hasil dari keseluruhan conditional probabilitas pada setiap variabel input sesuai dengan class masingmasing dengan nilai dari class probabilitas. Sistem akan menampilkan hasil prediksi dari perhitungan menggunakan metode Naïve Bayes.

Proses juga digambarkan oleh diagram konteks yang merupakan gambaran dasar dari sistem. Dimana terdapat 2 user yaitu user admin dan user opd. Setiap user tersebut memiliki hak akes yang berbeda-beda di setiap fitur yang terdapat pada sistem klasifikasi tingkat kesejahteraan keluarga.

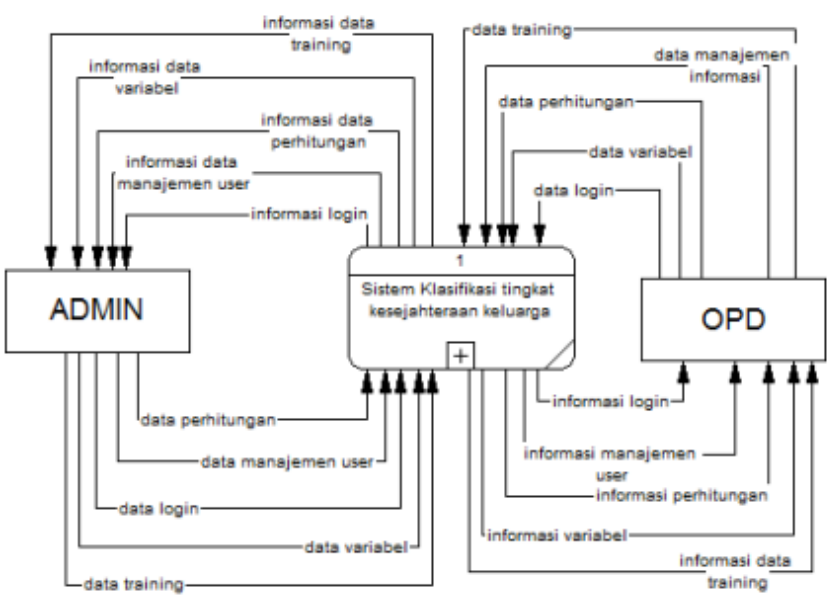

Gambar 2. Diagram konteks system klasifikasi pada

\section{tingkat kesejahteraan keluarga}

Proses yang lebih detail pada sistem dijabarkan dalam Data Flow Diagram (DFD) level 1 [11]. Terdapat 5 proses yang terjadi yaitu dari proses pencarian data training, proses hapus data training, proses perhitungan proses pengaturan variabel dan proses pengaturan manajemen user, dimana pada semua proses dapat di akses oleh user admin, sedangkan user opd hanya dapat melakukan proses pencarian data training, proses perhitunga dan proses pengaturan manajemen user. Berikut gambar DFD level 1 sistem klasifikasi pada tingkat kesejahteraan keluarga.

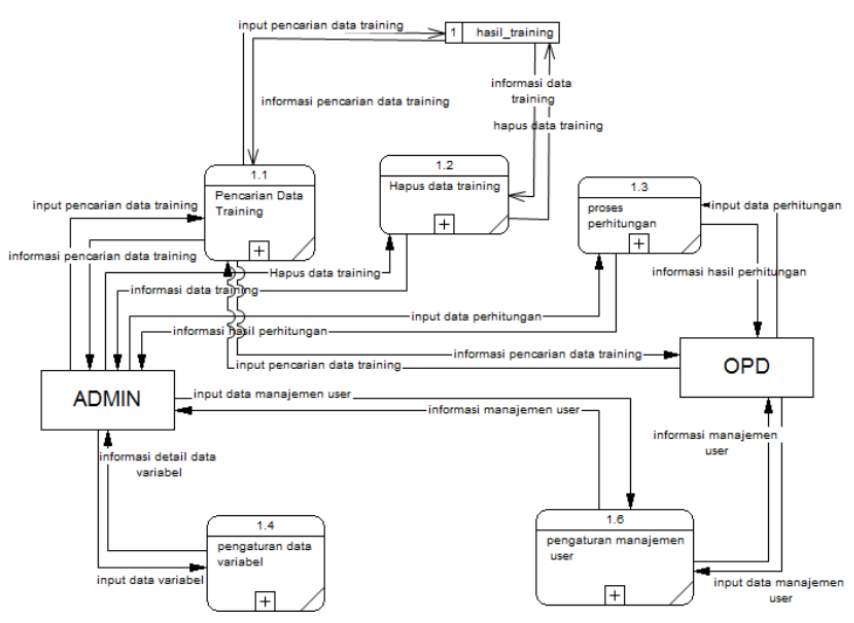

Gambar 3. DFD level 1 pada sistem klasifikasi tingkat kesejahteraan

\section{HASIL}

Tampilan awal system adalah halaman login untuk yang dapat diakses dengan menginputkan user dan password.

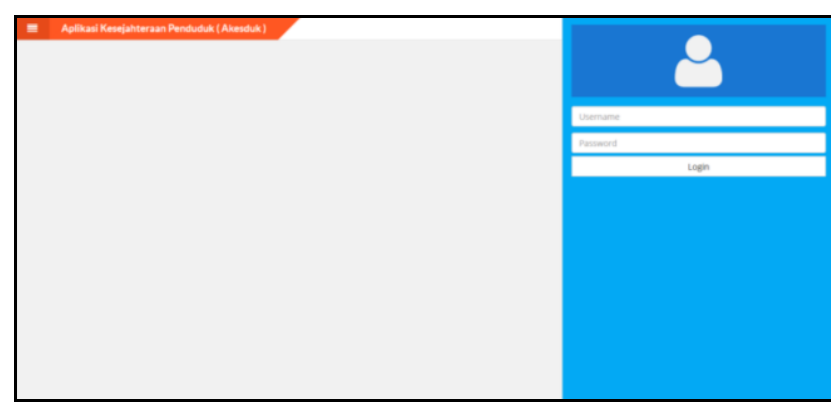

Gambar 4. Halaman login

Berikut adalah tampilan untuk menu perhitungan yang dipergunakan untuk melakukan proses perhitungan naïve bayes dengan memasukkan data detail keluarga dan memasukan semua variabel masukkan yang digunakan dalam perhitungan. 


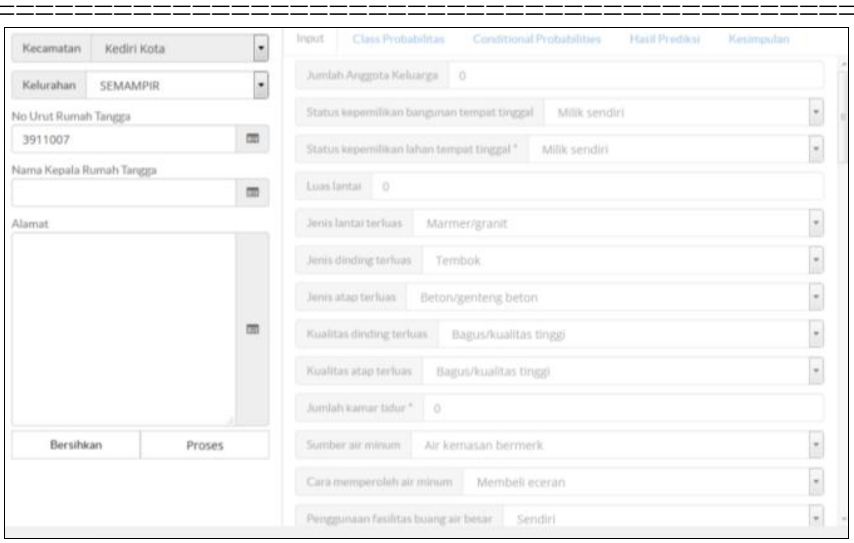

Gambar 5. Tampilan halaman input data perhitungan

Halaman data training digunakan untuk mengakses data training yang akan digunakan untuk proses perhitungan atau melihat hasil perhitungan yang telah disimpan.

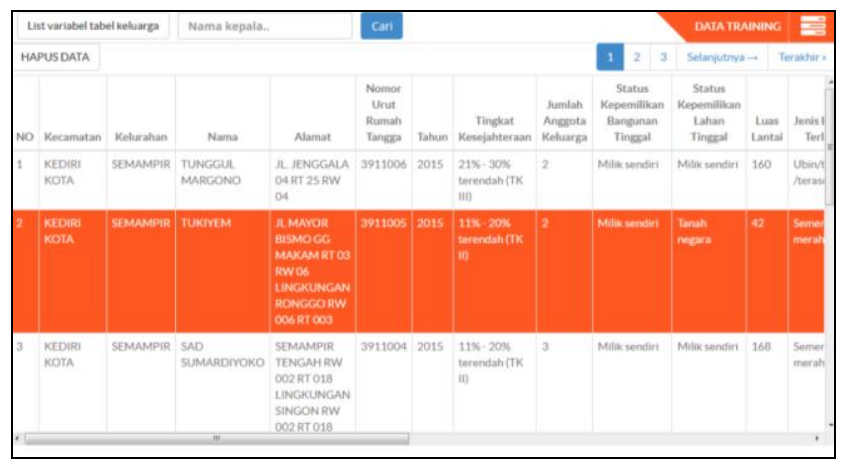

Gambar 6. Halaman variable

Dalam penentuan tingkat kesejahteraan keluarga berdasarkan informasi Pemutakhiran Basis Data Terpadu (PBDT) keluarga dilakukan melalui proses pengklasifikasian dengan 53 variabel input yaitu Jumlah Anggota Keluarga, Status kepemilikan bangunan tempat tinggal, Status kepemilikan lahan tempat tinggal, Luas lantai, Jenis lantai terluas, Jenis dinding terluas, Jenis atap terluas, Kualitas dinding terluas, Kualitas atap terluas, Jumlah kamar tidur, Sumber air minum, Cara memperoleh air minum, Penggunaan fasilitas buang air besar, Jenis kloset, Tempat pembuangan akhir tinja, Sumber penerangan utama, Daya listrik terpasang (PLN), Bahan bakar untuk memasak, Kepemilikan tabung gas $5.5 \mathrm{~kg}$ atau lebih, Kepemilikan sambungan telepon (PSTN), Kepemilikan komputer/laptop, Kepemilikan Sepeda, Kepemilikan Sepeda motor, Kepemilikan Mobil, Kepemilikan Perahu, Kepemilikan Motor tempel, Kepemilikan Perahu motor, Kepemilikan Kapal, Kepemilikan Lemari es/kulkas, Kepemilikan AC (penyejuk udara),
Kepemilikan Pemanas air (water heater), Kepemilikan Televisi, Kepemilikan Emas/perhiasan/tabungan senilai 10 gram emas, Jumlah nomor HP aktif, Jumlah TV layar datar minimal 30inchi, Kepemilikan aset lahan lain, Luas lahan yang dimiliki, Kepemilikan aset rumah di lokasi lain, Ada anggota rumah tangga yang memiliki usaha sendiri/bersama, Jumlah ternak sapi yang dimilki, Jumlah ternak kerbau yang dimilki, Jumlah ternak kuda yang dimilki, Jumlah ternak babi yang dimilki, Jumlah ternak kambing/domba yang dimilki , Peserta Program Kartu Keluarga Sejahtera (KKS)/Kartu Perlindungan Sosial (KPS), Peserta Program Keluarga Harapan $(\mathrm{PKH})$, Peserta program Beras untuk Orang Miskin (Raskin), Peserta program Kredit Usaha Rakyat (KUR), Memiliki Kartu Indonesia Pintar (KIP)/Bantuan Siswa Miskin (BSM), Memiliki Kartu Indonesia Sehat (KIS)/BPJS Kesehatan/Jamkesmas, Memiliki BPJS Kesehatan peserta mandiri, Memiliki Jamsostek/BPJS ketenagakerjaan, Memiliki Asuransi kesehatan lainnya dengan menggunakan metode Naïve Bayes untuk mendapatkan hasil perhitngan probabilitas class dan conditional probabilitas yang akan menghasilkan prediksi tingkat kesejahteraan keluarga.

Berikut hasil sampel data training pada tingkat kesejahteraan keluarga dalam pengujian:

Tabel 1. Data Kasus

\begin{tabular}{|c|c|c|}
\hline No & VARIABEL & NILAI \\
\hline 1 & Jumlah Anggota keluarga & 2 \\
\hline 2 & Status Kepemilikan Bangunan Tinggal & Milik sendiri \\
\hline 3 & Status Kepemilikan Lahan Tinggal & Milik sendiri \\
\hline 4 & Luas Lantai & 160 \\
\hline 5 & Jenis Lantai Terluas & Ubin/tegel/teraso \\
\hline 6 & Jenis Dinding Terluas & Tembok \\
\hline 7 & Kualitas Dinding Terluas & $\begin{array}{l}\text { Jelek/kualitas } \\
\text { rendah }\end{array}$ \\
\hline 8 & Jenis Atap Terluas & Genteng tanah liat \\
\hline 9 & Kualitas Atap Terluas & $\begin{array}{l}\text { Jelek/kualitas } \\
\text { rendah }\end{array}$ \\
\hline 10 & Jumlah Kamar Tidur & 3 \\
\hline 11 & Sumber Air Minum & Sumur terlindung \\
\hline 12 & Cara Memperoleh Air Minum & Membeli eceran \\
\hline 13 & Sumber Penerangan Utama & Listrik PLN \\
\hline 14 & Daya Listrik Terpasang & 900 watt \\
\hline 15 & Bahan Bakar Untuk Memasak & Gas 3kg \\
\hline 16 & Penggunaan Fasilitas Bab & Sendiri \\
\hline 17 & Jenis Kloset & Leher angsa \\
\hline 18 & Tempat Pembuangan Akhir Tinja & SPAL \\
\hline 19 & Kepemilikan Tabung Gas & Tidak \\
\hline 20 & Kepemilikan Lemari Es & $\mathrm{Ya}$ \\
\hline 21 & Kepemilikan Ac & Tidak \\
\hline
\end{tabular}




\begin{tabular}{|l|l|l|}
\hline 22 & Kepemilikan Pemanas Air & Tidak \\
\hline 23 & Kepemilikan Sambungan Telepon & Tidak \\
\hline 24 & Kepemilikan Televisi & Ya \\
\hline 25 & Kepemilikan Emas Tabungan & Tidak \\
\hline 26 & Kepemilikan Komputer Laptop & Tidak \\
\hline 27 & Kepemilikan Sepeda & Tidak \\
\hline 28 & Kepemilikan Sepeda Motor & Ya \\
\hline 29 & Kepemilikan Mobil & Tidak \\
\hline 30 & Kepemilikan Perahu & Tidak \\
\hline 31 & Kepemilikan Motor Tempel & Tidak \\
\hline 32 & Kepemilikan Perahu Motor & Tidak \\
\hline 33 & Kepemilikan Kapal & Tidak \\
\hline 34 & Jumlah Nomor Hp Aktif & 2 \\
\hline 35 & Jumlah Tv Layar Datar & 0 \\
\hline 36 & Luas Lahan Yg Dimiliki & 160 \\
\hline 37 & Kepemilikan Rumah Lokasi Lain & Tidak \\
\hline 38 & Jumlah Ternak Sapi & 0 \\
\hline 39 & Jumlah Ternak Kerbau & 0 \\
\hline 40 & Jumlah Ternak Kuda & 0 \\
\hline 41 & Jumlah Ternak Babi & 0 \\
\hline 42 & Jumlah Ternak Kambing Domba & 0 \\
\hline 43 & Ada Anggota Keluarga Usaha & Tidak \\
\hline 44 & Memiliki Kks Kps & \\
\hline
\end{tabular}

Dari data kasus pada table dilakukan proses perhitungan untuk menghasilkan class probabilitas sebagai berikut:

Tabel 2. Class Probabilitas

\begin{tabular}{|l|l|l|}
\hline Class Probabilitas & Hasil & Decimal \\
\hline $\mathrm{P}(\mathrm{y}=0 \%-10 \%$ terendah (I) $)$ & $10 / 40$ & 0.25 \\
\hline $\mathrm{P}(\mathrm{y}=11 \%-20 \%$ terendah (II) $)$ & $10 / 40$ & 0.25 \\
\hline $\mathrm{P}(\mathrm{y}=21 \%-30 \%$ terendah (III) $)$ & $10 / 40$ & 0.25 \\
\hline $\mathrm{P}(\mathrm{y}=31 \%-40 \%$ terendah (IV) $)$ & $10 / 40$ & 0.25 \\
\hline
\end{tabular}

Hasil perhitungan menghasilkan

$\mathrm{P}(\mathrm{y}=0 \%-10 \%$ terendah (I) ) sebesar 0.25

$\mathrm{P}(\mathrm{y}=11 \%-20 \%$ terendah (II) ) sebesar 0.25

$\mathrm{P}(\mathrm{y}=21 \%-30 \%$ terendah (III) ) sebesar 0.25

$\mathrm{P}(\mathrm{y}=31 \%-40 \%$ terendah (IV) ) sebesar 0.25

Dimana hasil tersebut di ambil dengan jumlah total data sampel berjumlah 40 data sampel dan setiap sampel menggunakan jumlah yang sama pada setiap kriteria.

Selanjutnya dilakukan proses perhitungan conditional probabilitas berdasarkan jumlah total data dari setiap variabel input yang sesuai kriteria. Dari hasil proses perhitungan dengan mengkalikan setiap hasil conditional probabilitas setiap variabel input sesuai dengan variabel classsnya masing-masing. Hasil dari perhitungan nya adalah sebagai berikut:

Tabel 3. Hasil Perhitungan

\begin{tabular}{|c|c|c|}
\hline $\begin{array}{l}0 \%-10 \% \\
\text { terendah }\end{array}$ & $\begin{array}{c}0.25^{*} 0.3^{*} 0.4^{*} 0.1 * 0 * 0 * 0.9^{*} 1 * \\
0.8^{*} 1 * 0.2^{*} 0.1 * 0.1 * 1 * 0.1 * 0.9 * \\
0.4 * 0.9 * 0.1 * 1 * 0.2^{*} 1 * 1 * 1 * 0.1^{*} \\
1 * 1 * 0.1^{*} 0.1^{*} 1 * 1 * 1 * 1 * 1 * 0 * \\
1 * 0 * 1 * 1 * 1 * 1 * 1 * 1 * 0.1^{*} 0.7 * \\
1 * 0.7 * 1 * 1 * 0.1^{*} 1 * 0.7 * 1 * 1\end{array}$ & 0 \\
\hline $\begin{array}{c}11 \%-20 \% \\
\text { terendah }\end{array}$ & 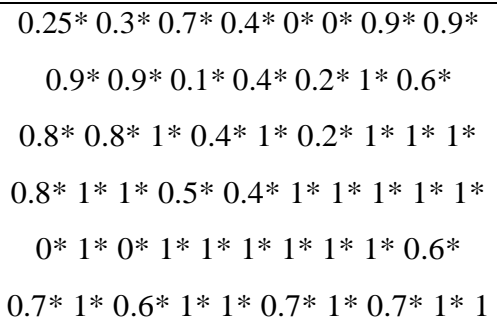 & 0 \\
\hline $\begin{array}{c}21 \%-30 \% \\
\text { terendah }\end{array}$ & 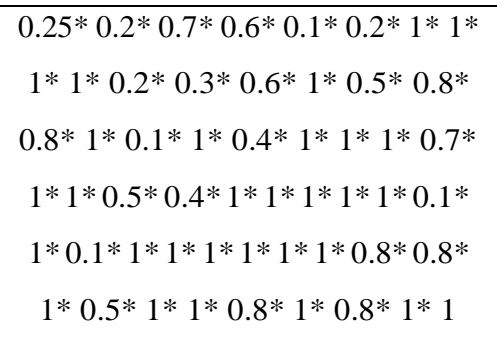 & $\begin{array}{c}0.00000 \\
000005 \\
549064 \\
192\end{array}$ \\
\hline $\begin{array}{c}31 \%-40 \% \\
\text { terendah }\end{array}$ & 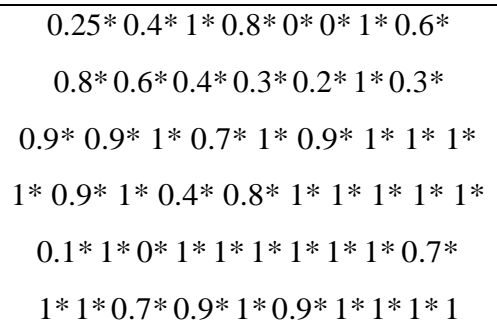 & 0 \\
\hline
\end{tabular}

Dari hasil tabel didapatkan hasil bahwa dari ke empat variabel class telah diperoleh hasil tertinggi yaitu sebesar 0.00000000005549064192 pada kriteria 21\%$30 \%$ terendah. Dari hasil tersebut kemudian dilakukan pengujian kembali menggunakan sampel data dan dihasilkan klasifikasi tingkat kesejahteraan keluarga.

Aplikasi yang dihasilkan dari penelitian ini mampu mengimplementasikan data mining menggunakan metode Naive Bayes untuk melakukan klasifikasi tingkat kesejahteraan keluarga dan memberikan prediksi tingkat kesejahteraan keluarga berdasarkan data pemutakhiran basis data terpadu dengan tingkat akurasi mencapai $87,2 \%$, berdasarkan hasil percobaan perbandingan data training dan data testing sebesar 80\%:20\%. 


\section{KESIMPULAN}

Telah dihasilkan aplikasi yang dapat digunakan untuk memprediksi tingkat kesejahteraan keluarga berdasarkan variable dari Pemutakhiran Basis Data Terpadu (PBDT) dengan tingkat akurasi mencapai $100 \%$ berdasarkan hasil uji coba sampel data.

Dari proses pengiplementasian data mining dengan menggunakan metode Naive Bayes untuk pengklasifikasikan tingkat kesejahteraan keluarga didapatkan aplikasi yang memiliki tingkat keakuratan yang tinggi dan memberikan prediksi tingkat kesejahteraan keluarga berdasarkan data pemutakhiran basis data terpadu dengan tingkat akurasi mencapai $87,2 \%$, berdasarkan hasil percobaan perbandingan data training dan data testing sebesar 80\%:20\%.

\section{DAFTAR PUSTAKA}

[1] BKKBN, "Profil Hasil Pendataan Keluarga Tahun 2011," in Badan Kependudukan dan Keluarga Berencana Nasional Direktorat Pelaporan dan Statistik, jakarta: Badan Kependudukan dan Keluarga Berencana Nasional Direktorat Pelaporan dan Statistik, 2011.

[2] E. Karyadiputra, E. Noersasongko, dan A. Marjuni, "KLASIFIKASI STATUS KESEJAHTERAAN RUMAH TANGGA KELUARGA BINAAN SOSIAL MENGGUNAKAN ALGORITMA NAIVE BAYES BERBASIS SELEKSI ATRIBUT CHI SQUARED," Cyberku J., vol. 12, no. 2, hal. 3-3, 2016.

[3] F. J. Simatupang, T. Wuryandari, dan Suparti, "Klasifikasi Rumah Layak Huni Di Kabupaten Brebes Dengan Menggunakan Metode Learning Vector Quantization Dan Naive Bayes," GAUSSIAN, vol. 5, no. 1, hal. 99-111, Jan 2016.

[4] G. Kishō-Kenkyūsho (Kyōto), H. K. Saputra, dan I. Novid, "The Meteorological notes of the Meteorological Research Institute Series 3.," $J$. Teknol. Inf. dan Pendidik., vol. 11, no. 2, hal. 55-62, Apr 2018.

[5] M. Han, J. \& Kamber, "Data Mining: Concept and Techniques Second Edition," in Morgan Kaufmann Publishers, San Francisco: Morgan Kaufmann Publishers, 2011.

[6] Maymunatu Azzainabiy, "Implementasi Metode Simple Additive Weighting Untuk Sistem Pendukung Keputusan Penentuan Warga Miskin Kota Pekalongan," Paradig. - J. Komput. dan Inform., vol. 19, no. 1, hal. $38-45,2017$

[7] C. R. Spritta, Y. D. Lulu, dan H. Rachmawati, "Aplikasi Teknik Classification Data Mining Kependudukan dengan Menggunakan Metode Naïve Bayes untuk Memprediksi Kondisi Penduduk (Studi Kasus: Kecamatan Luhak Nan Duo)," J. Aksara
Komput. Terap., vol. 3, no. 1, 2014.

[8] D. Iskandar dan Y. K. Suprapto, "Perbandingan akurasi klasifikasi tingkat kemiskinan antara algoritma C4 . 5 dan Naïve Bayes Clasifier," JAVA J. Electr. Electron. Eng., vol. 11, no. 1, hal. 14-17, Apr 2013.

[9] C. A. Ramadhan Suparman, E. Purwanti, dan P. Widiyanti, "Application Design of Dengue Hemorrhagic Fever Patients Screening Using Naive Bayes Method," J. Biomimetics, Biomater. Biomed. Eng., vol. 34, hal. 20-28, 2017.

[10] A. . Kenifesia, "Implementasi dan Study Analisis Data Mining Menggunakan Metode Bayesian untuk Menentukan Probabilitas Presentase Penerimaan Mahasiswa Baru Politeknik Caltex Riau,” in Politeknik Caltex Riau., Pekanbaru: Politeknik Caltex Riau., 2007.

[11] E. Turban, Decision Support Systems and Intelligent Systems. Yogyakarta: ANDI, 2005. 